Šarkić Nebojšs̆a*

Krstinić Dalibor**

https://orcid.org/0000-0002-9731-9178

Petrović Katarina ${ }^{* * *}$
UDK: 347.189:392.91

Original scientific paper DOI: $10.5937 /$ ptp2102001S

Received: 24.08.2020.

Approved on: 14.10.2020.

Pages: $1-16$

\title{
PERSONAL NAME
}

\begin{abstract}
The right to the personal name represents the most important expression of a personal identity, as well as an absolute subjective right of every individual. Furthermore, the individual is, through the personal name, distinguished in the known and social context, and it is also the means through which the state identifies its subjects. Without the existence of the personal name, the life within a community would be unimaginable, which means that this type of individualization is as old as the very human society. Nevertheless, through time, the means of such an individualization have been changed. Today, in Republic of Serbia, the personal name consists of a surname by which the belonging to a certain family community is expressed, and a name through which he/she is individualized within that community. The question of a personal name in our country is regulated by the Family Law and it is guaranteed by the Constitution. Given the importance of the personal name, the aim of this paper will be to demonstrate the important questions pertaining to the personal name, as well as the Family Law norms, by which it is regulated within the lawful context of Republic of Serbia.
\end{abstract}

Key words: personal name, surname, Republic of Serbia, the Family Law.

\footnotetext{
* Full Professor, The Faculty of Law in Belgrade, Union University in Belgrade, Serbia, e-mail: info@pravnifakultet.rs

** LLD, Assistant Professor, The Faculty of Law for Commerce and Judiciary in Novi Sad, The University of Business Academy in Novi Sad, Serbia, e-mail: krstinicdalibor@yahoo.com

${ }^{* * *}$ LLD, The Faculty of Law in Belgrade, Union University in Belgrade, Serbia, e-mail: katarina.petrovic@omv.com
} 


\section{Introductory remarks}

This paper begins with the general definition that the subjects of rights are also the carriers of rights and obligations. They can be individuals as natural persons or legal persons (Gams, 1982). As per Stanković and Vodinelić: "In today's column of social and legal development exist two types of legal subjects: people as individuals - natural persons, and organizations with legal capacity - legal persons" (2007, p. 51). The basic characteristic of natural persons is the name. The name is the permanent term for the individual, and it is regulated by law. That is how the Constitution of the Republic of Serbia (2006), article 64, paragraph 2, defines that every child has a right to the personal name, registration in the birth register, the right to know its origins, and the right to the preservation of its identity. The legal issues with determining, changing, and application of the personal name are numerous, which is why this question is discussed in several laws. However, the most important source of analysis for this subject, apart from the quoted constitutional definition, is the Family law of Republic of Serbia (2005).

In general provisions, Family law, paragraph 13 elaborates on the constitutional determinant of child rights which are expanded and indicated such that everyone has a right to the personal name. This right is considered to be the basic feature of every natural person. The right to determining personal name is acquired at birth and is later elaborated on by determining the imperative deadline by when the parents must agree on the child's name, or else it will be determined by the Guardianship authority. Therefore, this right which we recognize as one of the basic human rights is also an obligation on the parents since, as it will be demonstrated later on, that this right, in legal context, often appears as an obligation as well. Personal name can be changed under the lawfully regulated conditions, but there are numerous limitations pertaining to one's ability to change his name. The law dictates that the term "personal name" is a genus term for two separate segments: it is the name which we recognize as personally chosen and used by an individual, and his surname or family name, which is used by all or some members of the same family (Draškić, 2016; Draškić, 1998, p. 55; Počuča \& Šarkić, 2019, p. 81). Personal name enters the Birth register. As a reminder, there are three types of registries: birth, marriage, and death. The Birth Registry Law (2009), article 45 , dictates that the information which enters the birth registry is: the information on the birth of the child, name and surname, shortened personal name, sex, day, month, year of birth etc. while article $45 \mathrm{~b}$. dictates, in paragraph 1, that the information that enters the birth register also includes gender 
reassignment based on court decision..., whereas in article 4 it states that the information that is to be put in is: "...name and surname, date, place, municipality, city etc." The information that is also to be written in the birth register pertains the information on the adoptee: personal name, sex, day, month, year and hour of birth, place and municipality of birth, citizenship etc. The information on parents is replaced with the information of the adoptive parents.

We encounter the birth register again when entering a marriage, therefore in the article 55 of the Birth Registry Law on (2009) it is stipulated that the information on the change of the personal name, name, or surname, is to be written down in the marriage registry book. Family Law, article 342, stipulates also that everyone is obligated to use their personal name. For practical reasons, this obligation is further elaborated on by stating that individuals whose name or surname consists of more than three words is obligated to use the abbreviated personal name. The decision of shortened personal name is communicated to the registrar who keeps the birth register for the right holder, and it is then written down, in the registry book, which combination of the name and surname has been chosen by an individual.

\section{Determining the Personal Name}

The Family Law of the Republic of Serbia stipulates that the name of the child is to be chosen by the parents. In our opinion, erroneously, the legislator didn't indicate that this name must be chosen in mutual agreement by both parents. Even though in the very legal norm itself, this obligation of parents to agree upon the name of the child doesn't exist, it can be inferred from the following legal provision (article 345, paragraph 3 of Family Law) that the surname of the child is determined by the Guardianship Authority in the case of the parents' deaths, if the parents are unknown or if they are unable to come to an agreement pertaining to the child's name. Therefore, we can conclude that the legislator wished for the agreement on the name of the child.

By respecting the highest European standards pertaining to the rights of minorities, the law envisions the possibility that, during the process of determining the child's name, it can be determined by the linguistic rules of the language of the minority or the nationality of the group to which the child belongs, yet that the name written down in the birth register still be written down with respect to the linguistic rules (the way in which the given name is written).

Although naming a child represents a fundamental parental right, this right is limited by law inasmuch that the parent cannot give the child an 
abusive name, or one that is contrary to norms and customs of the environment. It is perfectly understandable that this is primarily about moral norms and customs. We must remind that morality is a shifting category and that it changed throughout time (pending on the historical context, moral values have changed), as well as geographically (different moral norms found in different countries or communities). This means that certain values which were accepted historically or in certain environments, became unacceptable over time or there was no such relationship with moral norms in different environment (Marjanović, 2016).

It is absolutely certain that generations born in the aftermath of World War II harbored serious animosity towards fascist leaders such as Adolf Hitler, and that naming a child "Adolf" was neither appropriate or desirable. Today's generations are distant from these historical events, therefore mentioning the name "Adolf" doesn't implicated such negative connotations as the case would be in the fifties in Yugoslavia. The determinants given by the law are pretty fluid and it is quite hard to determine which names would fall under this category. However, we believe that this provision must be interpreted in a restricting way and that it is the state's right to intervene only in the most drastic of cases when it is obvious that the name is based on vulgar or abusive terms. In certain mountain areas of Western Serbia or Bosnia, there was a custom, in cases in which daughters were born successively, to name the last female daughter "Dostana" - with the desire for her to be the last female child of the family. The authors of this paper express their own unacceptance of such or similar social norms which discriminate against female children, but it can hardly be said that the registrar has the right to forbid this name, just because it indirectly implies the parents' wish to have a male child (Damjanović, 2016).

The Guardianship authority has an important, although rarely utilized, role. The law gives the guardianship authorities a significant corrective role so that they can react and name the child in cases in which the parents fail to do so. This mainly refers to instances in which the child is orphaned (parents deceased, incapable of rationalizing, unavailable, deprived of their parental rights etc.); when they haven't made a mutual agreement pertaining to the name of the child and, within the given legal timeframe registered in the child in the birth register; when they gave an abusive or otherwise forbidden name to the child resulting in the inability to write the name in the birth register (article 344, paragraph 4 of Family Law).

Surname of the child - it has already been stated that the personal name consists of name and surname which represents the family name. In 
comparative law the surnames are determined in various ways. There are states in which the surname is determined based on the mother's surname (as the most accurate form of biological continuation), there are states in which it is determined by the father's name, according to the surnames of both parents etc. In our geographic area, however, the common practice is for the child to bear the surname of one of the parents. The surnames were created with the emergence of state structures in certain areas of South Slavic countries which necessitated the registration of individuals, therefore resulting in the necessity for both name and surname. In today's Lika or Bosnia and Hercegovina, following the Austro-Hungarian occupation, it is obligatory to determine both name and surname. Until then, the individuals were named and recording following the male ancestral line i.e. Petar Jankov, Janko, Markov, Marko Perov and so on. Unaware of the seriousness of Austro-Hungarian bureaucratic powers, many residents, believing that Austro-Hungarians wouldn't remain in the area, gave their children names in jest. This is resulted in surnames according to the occupation (Kolač, Pinter, Šnajder) or surnames according to nicknames (Guzina, Čubrilo, Kvrgić), (Damjanović, 2016).

According to the current laws in the Republic of Serbia, a child can carry the surname of one or both parents. Yet, in legal matters, it is a matter of agreement whether the child will use the mother's surname, the father's surname, or some combination of the two. The only imperative from law, is that children from the same marriage cannot have different surnames, therefore, if there is more than one child in one marriage, the siblings must carry the surname of the father, the mother or some combination of the two. The Guardianship authority has the same rights when it comes to the child's surname as it does with the child's name in cases in which the parents are deceased, unknown, or incapable of reaching an agreement.

\section{The change of the Personal Name}

Who has the right to change the name - in the third section of the Family Law of the Republic of Serbia, five paragraphs are dedicated to the topic of rights regarding name change. Every individual turning fifteen and capable of rationalizing has the right to change its name. Here the legislator decreases the necessary age of making the decision below the age of recognized adulthood which is prohibited given the paragraph 2 of the same article, which actually allows for the possibility that the child turning ten and capable of making an educated judgment has the ability to give consent to have its name changed (Family Law, 2009, article 346). Therefore, in first instance, 
the legislator determined that a child who turned fifteen has the ability to change its name, whereas a ten-year-old child is allowed to give constant in order to have its name changed.

In both cases, the legislator introduces the vague terminology of "the child capable of making an educated judgment". It is unclear whether this ability to reason can be determined by medical experts' examinations or whether it can be concluded in the process similar to that of giving consent to marriage. Unfortunately, in practice, this question isn't given its due attention, and registrars, it appears, readily and easily met and accepted name change when it came to underage persons. This issue's importance is especially emphasized when viewed in light of numerous child marriages (first and foremost in the Romani minority population, but also in certain areas of Southern Serbia), which is certainly opposed to the international standards and generally accepted principles of necessary reduction of child marriages (Medić, 2016).

Therefore, in accordance to our opinion, this question shouldn't be viewed in the context of "potential rights of the child" bur rather in the context of necessary security and legal framework. It is our opinion that these rights pertaining to the change of name or surname must refer only to individuals who already have employment capacity (after eighteen years of age, or sixteen to eighteen, following the permission to enter a marriage) and should be restricted in other cases. Unfortunately, throughout our analysis, it was concluded that the change most often occurred in cases in which more traditional names, in accordance to the ethnic customs of the group to which the child belonged, were changed to names more prominent in the world of showbusinesses, movies, music, sport etc.

Who does not have the right to change their name - In four articles, the law defines restrictions as it pertains to the potential name change. First and foremost, this refers to the individuals who are in the middle of criminal proceedings for acts for which they are to be detained by the law enforcement (practically the majority of criminal acts). Additionally, individuals who are convicted for criminal activities which are persecuted by the police until the conviction is enforced (this mainly refers to conditional releases, pardon, or the period following the serving of the sentence until deletion from the criminal records) (Family Law, 2005, article 347, paragraphs 1 and 2). Paragraph 3 , article 347 of Family Law is quite imprecise and it refers to an individual who attempts to avoid one of his obligations. This formulation of the law is, on one hand, logical, on the other, ineffective. The avoidance of obligations is an extremely wide concept which encompasses the most basic of things (I 
do not wish to throw out the trash or wash the dishes) and those that are more serious in nature (I do not wish to return the loan to the bank, or I do not wish to return my debts to individuals). We are of the opinion that the legislator could have determined a more measurable criterion while establishing this definition, given the existing one is too wide and therefore ineffective. A potential solution would be an individual willing to avoid an obligation which is a result of a court's decision, paying alimony, damages, execution of an administrative or a similar act, etc.

The last stipulation of prohibition returns to the question of determining the personal name as it is forbidden to change one's name to something that is vulgar or, according to established standards, unacceptable to the legislator. Here we would like to insert another reminder about the changing of moral and customary values and restrictive application of this norm (which should be practice, in our opinion). Although the stipulation of article 347 of the Family Law, might seem all encompassing and appropriate during the first read of the same, we can note that it is basically irrelevant in practice. We know from our everyday lives that even individuals from serious criminal background managed to successfully change their name (name or surname) and that there are practically no serious control mechanisms to combat this malpractice.

The change of the spouse's surname - Article 348 of Family Law (2005) stipulates the regulation of rights of the spouses when entering a marriage. Rather, it could be formulated in simpler fashion that all combinations are allowed, but the legislator resorted to utilize the system of enumeration, therefore the law is as follows: keep your surname; take your spouse's surname; add your spouse's surname to your own.

The legislator further envisions that the spouse who decided to change their name can, within 60 days of the marriage's termination, assume the surname he had prior to entering the marriage. In our opinion, this deadline is completely useless as the right to change one's surname is one of the fundamental rights enjoyed throughout one's entire life. On the other hand, it seems rather short as, in the case of, for example, termination of marriage due to death of one of the spouses, it seems that changing one's surname doesn't qualify quite highly on the list of one's priorities.

It should be noted here that the 60-day deadline is merely a general deadline referring to the termination of marriage. Here we would like to remind that the marriage ceases with one's death, annulment, or divorce. With annulment and divorce, special attention should be devoted to the 60-day deadline as it probably refers to the date of the court's decision on the marriage's 
termination. In cases in which the procedure for establishing all the relevant facts related to one's death and declaring a missing person deceased, the right to change one's surname within the 60-day timeframe should run from the day of the court decision from the non-litigious procedure on: establishing the facts of death, or the declaration of the missing person as a deceased.

Changing the child's surname - Family Law (2005) stipulates in article 349, three cases in which the surname of the child can be changed. First in imprecise and it states that the child's surname can be changed during the establishing of the mother or the father of the child, or rather in cases of contesting maternity or paternity. This formulation is legally incorrect and imprecise therefore it requires elaboration. Reasonable interpretation suggests that the legislator thought of cases in which paternity or maternity were still contested in court therefore, pending on the court's decision, should the child still not be recorded in the birth registry, the recording of the surname of the child would be conducted based on the court's decision regarding paternity or maternity.

Another situation implies litigation procedure contesting the registered maternity or paternity, situations which, intentionally or inadvertently, resulted in the replacement of babies within the maternity ward, resulting in the wrongful maternity records, or when the father of the child is recorded as the husband of the mother, even though the marriage has been terminated previously and the mother entered a new marriage or simply found a new partner who is the father of the child. In this second situation, it is possible to contest recorded paternity or maternity, and then ask for a change based on the court's decision. Another situation involves the adoption of a child. We know that our legal system recognizes only complete adoption, therefore adoption encompasses the process in which adoptive parents and the adopted child are recognized as having the relationship identical to those of biological parents and their child. In cases in which the child hasn't had its name or surname recorded in the birth register, the information that enters the register is the one determined by adoptive parents. In cases in which the surname has been recorded (in cases in which the parents are alive yet they gave up or were relieved of their parental duties) a new surname shall enter the register. The child's surname will henceforth be recorded following the general rules pertaining to the determination of the child's surname when it comes from a marriage. That means that the child can have the surname of the adoptive mother, father, or any combination of the two.

One specific situation is elaborated in the stipulation of article 349 paragraph 3 of Family Law. Although that might be a rare situation in real life, it is quite delicate. It is conceivable that an adoption is ceased through annulment. 
Such a situation requires that, a child which had already changed its surname through adoption, changes the surname again. This stipulation should be read within the context of stipulation of paragraph 276 of the same law in which the effects of a court decision, regarding the annulment of adoption, are taken into account. The verdict on annulment of adoption is passed based on legally foreseeable reasons, and the same verdict is then placed before the guardianship authority on which the adoption is based. Based on this verdict, the guardianship authority makes a decision regarding the decision of the annulment of the new registration in the birth register. Based on the same decision, the original inscription in the birth register is strengthened, resulting in the resolution of the eventual change of the name or surname.

Who has actual, and who has local jurisdiction to make a decision The request to change the personal name is to be submitted to the municipal authority in which the applicant has a permanent or temporary residence. The municipal authority is obligated to inform the appropriate registrar about the application for the name change for the purpose of recording the change in the birth and marriage register, as well as to report it to the authority on the recording of the residence of individuals. The law stipulates a two-stage procedure, and an appeal to change the personal name can be filed with the Ministry responsible for the protection of the family (Ministry of Labor, Employment, Veterans and Social Affairs) within 15 days of receiving the decision.

One can file an appeal against the negative decision of the second-instance authority (ministry in charge of social politics) to the administrative court which has local jurisdiction to make decisions for the whole of the Republic of Serbia, and which has actual jurisdiction to decide on the control of legality of administrative bodies (article 350 of Family Law).

\section{The protection of rights to a Personal Name}

The violation of rights to a personal name - Family Law regulates the question of violation of rights to a personal name in 6 articles. To understand the essence of the protection of rights to a personal name, it is first necessary to analyze the legally predicted cases in which a violation of rights to a personal name can occur:

The violation is committed by an individual who prevents another individual from using their personal name. The same prohibition applies to an individual obstructing the usage of part of the name (name or surname, or any other impediment to using of one's name) - the prevention and obstruction of utilizing the right to a personal name. 
In cases in which an individual, intentionally or through extreme negligence, prescribes another name or a part of the name to an individual, or claims that the holder of the name is obligated to use another name or part of the name. This can happen in cases in which the personal name or surname has a foreign origin, or the way in which the name is written doesn't match the rules in which the Serbian language is written. Referring to or labeling an individual with a different personal name is the contesting of one's right to a personal name - contesting the right to a personal name.

In case in which an individual intentionally or through extreme negligence in a written word, public addressing, or any other public communication, distorts someone's personal name, by shortening it, expanding it or otherwise violating the holder's personal rights, constitutes a violation of the right to a personal name. The law stipulates an exception labeling it "unless when customary or necessary," which is vague and ineffective for usage. It leaves room for an individual, who commits this injury of a right to a personal name, for other reasons, to utilize this as his own defense claiming that he did so, in fact, because it was customary or necessary. This usually occurs when someone's name is shortened or changed into another name without the necessary consent by the name holder: "Jelena into Jeca, Jeka, Lela etc. or Aleksandar into Aca, Aleks, Saša etc." - distortion of one's personal name (Babić, 2014).

The violation to one's personal name also occurs when an individual presents himself under another name, or rather when someone uses another's name for their own purposes. Another violation occurs when one incites another, or allows another, to present themselves using the holder's name or part of the name. In this group of unauthorized usages of a name, the law also includes cases in which a name, or a part of the name, is used for a certain purposes without the consent of the name holder in cases in which the name is "shortened, expanded, translated from a foreign language etc." - unauthorized usage of a personal name (article 351 of Family Law).

It appears that all four instances are not precise enough when it comes to the possibility of realization of one's rights. The terms that are used are imprecise (definite or identifiable), and they can enable someone who intentionally, or through extreme negligence, committed an injury to the rights to a personal name, to use that as a facilitating or justifying argument.

Consent to the usage of a name - the provision of article 352 of Family Law (2005) provides for the possibility that the holder of the name, with or without compensation, allows for his personal name, or part of the name, to be used for designated purposes. As a condition, it is first necessary that an 
individual gives consent, although it isn't elaborated on what type of a consent is necessary. Whether said consent can be oral, whether a written agreement is necessary, or whether it might even be necessary to give consent in front of the notary or some other appropriate form is not specified.

The law also stipulates that the name can be used only in purposes previously agreed upon and approved by the holder, which seems logical and justifiable. To that extent, famous persons (athlete, scientist, artist) can allow for their name to be used in humanitarian purposes, with or without a compensation.

Regarding the giving consent to using one's surname, it is necessary to also gain the consent of other individuals to whom the holder's surname is applied. Given the circumstances, the Family Law (2005, Article 352, paragraph 2) stipulates that this consent would also encompass the spouse, child, parents, and others, if the usage of the surname would be violation to their rights. Of course, the usage of a designation "and others" is imprecise and ineffective. To what degree of kinship the rule to obtain consent applies is not clear enough, and it seems that enumerating the closes family members is sufficient, therefore an further expansion is actually unnecessary.

The legislator stipulates that the consent given for a specific purpose can only be attributed to that, or a similar purpose. Using the personal name for another purpose is not allowed, therefore the once given consent cannot be considered as a consent for all other, potential situation or for the repetition of the same situation, for which the original consent was given. Here, then, the legal determination is very restrictive in regards to consent, therefore it is necessary to acquire consent for each and every usage of the name.

Revocation of consent - The legislator allows for two possibilities. One is that the holder retains the right to revocation of consent, the other that the holder has no right to revocation. In cases in which the individual doesn't retain the right to revocation of consent to using his name, this right could be requested only in cases in which it can be proved that the using of our name will be extremely harmful for our interests. Here, the legislator doesn't really indicate what type of interests are referred to, but it certainly refers to moral integrity, professional reputation and honor, property rights etc. Additionally, the law stipulates that a condition for this situation must be the holder's inability to anticipate the harmful ensuing events which can ensue from someone using his name (article 354 Family Law, 2005). Certainly, the right to compensation can be requested by the person who had the consent to use another's name, should the revocation ensue. That person can prove that the 
using doesn't really harm the holder's interests (regardless of what type of interests are referred to) or that such consequences could have been predicted.

Lawsuits - Article 355 of the Family Law (2005) stipulates that a person whose right to a personal name is violated can, in a civil litigation, request the following: to determine the existence of the right to use his personal name, in case in which that right is injured intentionally or through extreme negligence. That the court orders removal, destruction, or alterations of items (phono recordings, video recordings, newspaper texts, publication of a magazine etc.) in which the injury to one's right regarding their personal name has occurred. Additionally, this type of a lawsuit refers to the obligation of withdrawing the claim in which the holder's right to a personal name is disputed or, in the widest sense of the word, remove the state of violation of the right. The lawsuit can be used for the prohibition of further usage or repetition of the act which violated the individual's right to name, under the threat of a monetary penalty, should the action of violating the holder's right to name continue or is repeated. The legislator doesn't concern himself with the amount of money, but allows for the court in civil proceedings to determine the amount that is to be paid for this type of abuse (Dudaš, 2006).

The lawsuit may be directed towards awarding compensation for material and immaterial damages for some of these injuries. Here we will use the basic rules of compensation which entail, firstly, the establishment of basis for the compensation, and then the amount of compensation. The damages caused can be, certainly, material and immaterial. As material damage, we recognize real costs caused to the holder of the name, reduction of his property, or other forms of establishing the material damages. In regards to the immaterial damages, we are primarily referring to the violation of honor, reputation, psychological pain, potential fear etc. (Bećirović-Alić \& Ahmatović-Ljajić, 2018).

The court can also rule a part of the profit made by the use of the personal name, in regards to the extent to which the personal name contributed to making of the profit. Here it is certainly hard to establish exactly how much the use of the name contributed the profit making of the abuser of another's personal name. Perhaps this could best be illustrated with an example of lessknown singer using the name or pseudonym of a more famous singer. Whether the profits made realized though the quality of performance itself, or realized through the unauthorized usage of a name or pseudonym of a famous person? The general rules on proving will apply here, with the note that the rights from this category of copyright infringement are hard to achieve (Marković \& Miladinović, 2014). 
In the case that the holder of the right to a personal name had deceased, following the violation and should the violation be committed prior to the individual's death, the right to the protection of the personal name and other forms of protection can be requested by the persons authorized by the deceased to take care of his name protection: spouse, child, parents of the deceased (article 356, Family law, 2005).

\section{Closing remarks}

Despite the limitation in the scope of this paper, it is clear how complex and serious the question regarding the legal regulation of one's personal name is. This field must be analyzed from several viewpoints:

- Customs are extremely present in this field of study. There is almost no territory in the world which doesn't have its own set of rules regarding the determination of the name (by father, grandfather, mother, using the surname of the father and mother etc.)

- Religious influences are also very present. An example can be made, in Christian tradition, of the most recognizable female names like Mary, while for the male ones those are Peter, Paul, John. For Orthodox Christians as the prevalent religious group in Serbia, the names are: Sava, Nemanja, Stefan, Rastko, etc. It is similar in other countries and religions: Mohammad, Buddha, Moses etc. The influence of religion on the determination of the name can be seen in the role of a godfather who, in Christian tradition, mostly on his own authority, or in agreement with the parents, determines the child's name. There are special church names which are registered in church registers and are different sometimes, from the names used in everyday or, rather, secular life.

- The Criminal Law, although to lesser extent, also regulates the questions pertaining to potential abuse of names and surnames (falsification, abuse etc.)

- The matter of personal name is one of the most complex fields of international commercial law. The reason for this is the fact that there are huge differences in the interior legal systems of the states, as well as the difference in the way and scope of the regulation of this matter in the national legislations.

- Unfortunately, our legislator still hadn't decided to draft a special Law on Personal Name, as was done by the legislator in the Republic of Croatia (the law on Personal Name of the Republic of Croatia, 1992). 
The field of personal name within our legal system is regulated in the Family Law which, in our opinion, is neither logical from the standpoint of the subject matter, or effective from the viewpoint of practical usage. We believe it would be valuable to adopt a new, special law, regarding the personal name. It would be possible to regulate in more detail the question of: giving the personal name, its use, potential abuses, the protection options etc. The Family Law should certainly retain the stipulations addressing the obligations for parents to agree on child name, as well as the determination of the surname that the child will use. Other provisions should, in our opinion, be in a separate law. In support of this view we also cite numerous disadvantages which appeared with this practice, in terms of: inability to prevent the abuse of change of the name and surname, a more detailed elaboration of the change of one's name in cases of gender reassignment surgery, adoption, change of citizenship, witness protection program, etc.

Although the matter of the personal name appears commonplace and well-known, in its simplicity, it hides a large number of complicated issues which we have tried to answer in this paper.

\section{Šarkić Nebojša}

Redovni profesor, Pravni fakultet u Beogradu, Univerzitet Union u Beogradu, Srbija

\section{Krstinić Dalibor}

Doktor pravnih nauka, docent, Pravni fakultet za privredu i pravosuđe u Novom Sadu, Univerzitet Privredna akademija u Novom Sadu, Srbija

\section{Petrović Katarina}

Doktor pravnih nauka, Pravni fakultet u Beogradu, Univerzitet Union u Beogradu, Srbija

\section{LIČNO IME}

REZIME: Pravo na lično ime predstavlja najvažniji izraz ličnog identiteta, kao i apsolutno subjektivno pravo svakog pojedinca. Pored toga ličnim imenom se izdvaja pojedinac u poznatom i društvenom kontekstu, a predstavlja i sredstvo kojim država identifikuje svoje subjekte. Bez postojanja ličnog imena život u zajednici bi bio nezamisliv, što znači da je ova vrsta individualizacije stara koliko i samo ljudsko društvo. Ipak, vemenom su 
se menjali načini ove individalizacije. Danas, se u Republici Srbiji lično ime sastoji od prezimena, kojim se izražava pripadnost određenoj porodičnoj zajednici i imena kojim se pojedinac individualizuje unutar zajednice. Pitanje ličnog imena u našoj državi regulisano je Porodičnim zakonom i garantovano je Ustavom. S obzirom na značaj ličnog imena, cilj ovog rada biće prikaz pitanja koja su relevantna i u vezi sa ličnim imenom, kao i norme Porodičnog zakona kojim se ono reguliše u zakonodavstvu Republike Srbije.

Ključne reči: lično ime, prezime, Republika Srbija, Porodični zakon.

\section{References}

1. Babić, I. (2014). Komentar Porodičnog zakona: prema stanju zakonodavstva od 1. februara 2012. godine [Commentary on Family Law: In accordance to The State of Legislation from February 1, 2012]. Beograd: Službeni glasnik

2. Bećirović-Alić, M. \& Ahmatović-Ljajić, A. (2018). Naknada nematerijalne štete u teoriji i sudskoj praksi Republike Srbije [Compensation of Immaterial damages in theory and practice of Republic of Serbia]. Ekonomski izazovi, 7 (13), pp. 140-152

3. Draškić, M. (2016). Komentar porodičnog zakona: praksa Evropskog suda za ljudska prava, praksa Ustavnog suda, praksa redovnih sudova : prema stanju zakonodavstva od 1. decembra 2015. godine [Commentary on Family Law: The Practice of European Court of Human Rights, Practice of Constitutional Court, Practice of Regular Courts: According to the state of legislation from December 1, 2015]. Beograd: Službeni glasnik

4. Draškić, M. (1998). Porodično pravo [Family Law]. Beograd: Dosije; Budapest: Colipi

5. Damjanović, D. (2016). Personal Name: the Gap in the PIL Acts of Republic of Srpska and Federation of Bosnia and Herzegovina In: Živković M. (ed). 4th Balkan Conference Conference Proceedings Personal Name in Internal Law and Private International Law (pp. 129144). Niš: University of Niš, Faculty of Law

6. Dudaš, A. (2006). Naknada štete zbog povrede ličnih prava autora [Compensation of Damages Due to Copyright Infringement]. Zbornik radova Pravnog fakulteta, Novi Sad, 40 (2), pp. 263-288 
7. Gams, A. (1982). Uvod u građansko pravo [Introduction to the Civil Law]. Beograd: Naučna knjiga

8. Marjanović, S. (2016) Personal name in Serbian family law and private international law de lege lata and de lege ferenda. In: Živković M. (ed.). 4th Balkan Conference, conference proceedings: Personal Name in Internal Law and Private International Law (pp. 91-112), Niš: University of Niš, Faculty of Law

9. Marković, S. \& Miladinović, Z. (2014). Autorsko pravo i srodna prava [Copyright and Similar Rights]. Kragujevac: Pravni fakultet; Institut za pravne i društvene nauke

10. Medić, I. (2016). Right to personal name and Croatian legal frameworkde lege lata and de lege ferenda. In: Živković, M. (ed.). 4th balkan Conference Proceedings: Personal name in International Law and Private International Law (pp. 71-89). Niš: University of Niš, Faculty of Law

111.Počuča, M. \& Šarkić, N. (2019). Porodično pravo i porodičnopravna zaštita [Family Law and Family Law Protection]. Beograd: Pravni fakultet Univerziteta Union: Službeni glasnik

12. Porodični zakon [Family Law]. Službeni glasnik $R S, 18 / 05,72 / 11-\mathrm{dr}$. zakon and $6 / 15$

13. Stanković, O. \& Vodinelić, V. (2007). Uvod u građansko pravo [Introduction to Civil Law]. Beograd: Nomos

14. Ustav Republike Srbije [Constitution of Republic of Serbia]. Službeni glasnik $R S$, no. 98/06

15. Zakon o matičnim knjigama [The Birth Registry Law]. Službeni glasnik $R S$, no. 20/09, 145/14 and 47/18

16. Zakon o osobnom imenu Republike Hrvatske [Law on Personal Name of Republic of Croatia]. Narodne novine no. 69/92, 26/93 and 29/94, $118 / 12,70 / 17,98 / 19$ 